\title{
Relationship between morpho-agronomic traits in tomato hybrids
}

\section{Relación entre caracteres morfoagronómicos en híbridos de tomate}

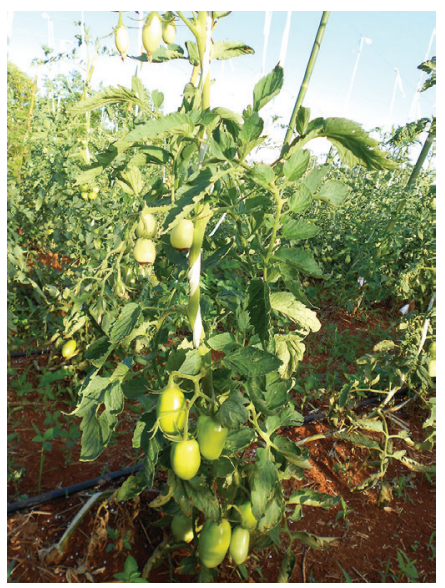

MARIA INÊS DIEL',

DÉBORA TURCHETTO ZAMBAN ${ }^{2}$

TIAGO OLIVOTO'

DIONATAN KETZER KRYSCZUN'

MARCOS VINÍCIUS MARQUES PINHEIRO²

BRUNO GIACOMINI SARI'

DENISE SCHMIDT ${ }^{2}$

ALESSANDRO DAL'COL LÚCIO'

\section{Experimental tomato crop.}

Photo: D.T. Zambam

\begin{abstract}
The objective of this study was to identify and estimate the relationships between production component variables and fruit yields in tomatoes. This experiment was conducted in a randomized block design with a $2 \times 3 \times 3$ factorial arrangement, with two tomato hybrids (Netuno and San Vito), three doses of boron $\left(\mathrm{H}_{3} \mathrm{BO}_{3}\right.$ - 0, 2, 4 g/pit) and three calcium floral applications (no application; application every 7 days; and application every 14 days), totaling 18 treatments with four replications and 20 plants per plot. Pearson correlation coefficients were estimated between the measured variables and, after that, those with greater significance were selected for productivity with the Stepwise method and verification of multicollinearity using the number of condition and inflation factor of the variance. The correlations of the selected variables were decomposed into direct and indirect effects on fruit productivity with path analysis. There was a strong correlation between the variables, excluding the variables height, diameter and average mass of the fruits. Thus, there were cause and effect relationships between the independent variable total mass of the fruits and the principal variable total fruit yield. The variables diameter and total number of fruits did not contribute to an increased tomato production.
\end{abstract}

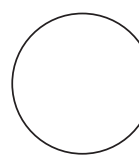

Additional key words: Solanum lycopersicum; path analysis; Pearson's correlation; multicollinearity; Stepwise; plant nutrition.

\footnotetext{
Universidade Federal de Santa Maria, Crop Science Department, Santa Maria (Brazil). ORCID Diel, M.I.: 0000-00027905-2166; ORCID Olivoto, T.: 0000-0002-0241-9636; ORCID Krysczun, D.K.: 0000-0002-7991-8994; ORCID Giacomini Sari, B.: 0000-0003-3405-9628; ORCID Lúcio, A.D.C.: 0000-0003-0761-4200

2 Universidade Federal de Santa Maria, Department of Agronomic and Environmental Sciences, Frederico Westphalen (Brazil). ORCID Zamban, D.T.: 0000-0003-1054-6472; ORCID Pinheiro, M.V.M.: 0000-0002-5028-7818; ORCID Schmidt, D.: 0000-0002-9963-4956

3 Corresponding author: mariaines.diel@hotmail.com
} 


\section{RESUMEN}

El objetivo de este trabajo fue identificar y estimar las relaciones entre variables componentes de producción y rendimiento de frutos en tomate. El experimento se realizó con diseño de bloques al azar con un arreglo factorial $2 \times 3 \times 3$, correspondiendo a dos híbridos de tomate (Netuno y San Vito), tres dosis de boro $\left(\mathrm{H}_{3} \mathrm{BO} \mathrm{O}_{3}-0,2,4 \mathrm{~g} /\right.$ sitio) y calcio (si aplicación, aplicación cada 7 días y aplicación cada 14 días), para un total de 18 tratamientos, cuatro repeticiones y 20 plantas por parcela. Se estimaron los coeficientes de correlación de Pearson entre las variables medidas, posteriormente, se seleccionaron aquellos con mayor significancia para la productividad mediante el método Stepwise y la verificación de la multicolinealidad por el número de condiciones y el factor de inflación de la varianza. Las correlaciones de las variables seleccionadas fueron descompuestas en efectos directos e indirectos sobre la productividad de los frutos mediante el análisis de coeficientes de trayectoria. Se encontró una fuerte correlación entre las variables, excluyendo las variables altura, diámetro y masa promedio de los frutos. Por lo tanto, existen relaciones de causa y efecto entre la variable independiente la masa total de frutos y la variable principal de productividad total de frutos, y las variables diámetro y número total de frutos no contribuyeron a aumentar la productividad de tomate.

Palabras clave adicionales: Solanum lycopersicum; coeficientes de trayectoria; correlacion de Pearson; multicolinealidad; Stepwise; nutrición de plantas.

Received for publication: 26-04-2018 Accepted for publication: 29-03-2019

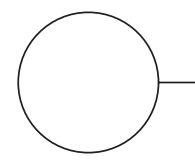

INTRODUCTION

Around the world, more than 5 million hectares are cultivated with tomatoes (Solanum lycopersicum), from which approximately 171 million tons of fruits are harvested, totaling $33.98 \mathrm{t} \mathrm{ha}^{-1}$ (FAOSTAT, 2018). These data prove the great economic and social importance of this crop. In Brazil, the cultivated area in the main producing regions totaled 37,398 ha in 2016, of which 18,674 were for table and 18,724 for industry (Kis and Carvalho, 2017). Globally, 4,782,753 ha are cultivated, with production reaching 17,7042,359 t (FAOSTAT, 2018).

Usually, when working with the tomato crop, a large number of variables are measured in order to obtain a set of data that allows the most varied types of evaluations and statistical analyses. When numerous variables are studied at the same time, correlations can be calculated between them, which are important for the selection of characteristics of interest for plant breeding (Moreira et al., 2013); for this, Pearson's correlation is used. However, care must be taken because, in many cases, it may not be a real measure of cause and effect, leading to misunderstandings during the interpretation of the data. In this way, path analysis is a statistical analysis capable of recognizing cause and effect relationships (Wright, 1921), unfolding the correlation coefficients in direct and indirect effects of independent variables on a dependent variable. According Rafiei and Saeidi (2005), this method is more coherent than simple linear correlations because they do not provide accurate information on each characteristic.

In this type of cause and effect relationship analysis, the presence of multicollinearity between the explanatory variables is common, and this factor may cause misunderstandings in the interpretation of the results (Cruz et al., 2012; Olivoto et al., 2017). Thus, it is extremely important to perform the multicollinearity diagnosis before carrying out the path analysis in order to obtain more accurate estimates of the direct and indirect effects on the studied dependent variable (Lúcio et al., 2013; Toebe and Cargnelutti Filho, 2013).

In the Stepwise method for selecting variables, the selection procedure is performed automatically with statistical packages, selecting a model with variables that explain the behavior of the dependent variable and that can be used to select variables that cause multicollinearity in the regression analysis linear (Zhang, 2016). Criteria for selecting variables include adjusted R-squared, Akaike information criterion (AIC), and Bayesian information criterion (BIC), among others (Hocking, 1976; Hosmer et al., 1989).

In this context, the objective of this study was to identify and estimate the relationships between the variables of production components and the total productivity of tomato fruits. 


\section{MATERIAL AND METHODS}

This study was conducted at the Federal University of Santa Maria (UFSM), Campus Frederico Westphalen $\left(27^{\circ} 23^{\prime} \mathrm{S}, 53^{\circ} 25^{\prime} \mathrm{W}\right.$ and $493 \mathrm{~m}$ of altitude) over two years of cultivation (2012 and 2013). According to the classification of Köeppen, the region's climate is $\mathrm{Cfa}$, humid subtropical, with an annual average precipitation of $1,800 \mathrm{~mm}$ well distributed throughout the year and subtropical from the thermal point of view (Alvares et al., 2013).

The soil preparation for plant cultivation was carried out with the conventional system. For the planting of the seedlings, grooves with a depth of approximately $20 \mathrm{~cm}$ were made, with a basic fertilization sequence, according to the soil analysis and the recommendation of the Soil Chemistry and Fertility Commission (COFSRS/SC, 2004).

The hybrid seedlings of the Italian type group (Netuno and San Vito) were produced in polystyrene trays with 128 cells in a greenhouse. Carolina $₫$ commercial substrate was used, and, after sowing, the trays were kept in a floating system. The transplant occurred on September 4, 2012 and January 26, 2013, when they presented five definitive leaves. Spacings of $1.0 \mathrm{~m}$ between rows and $0.5 \mathrm{~m}$ between plants was used. The plants were trained vertically on a single stem with a wire when they reached $15 \mathrm{~cm}$ in height. Drip irrigation was used to meet the water requirements of the crop. During the cycle, the shoot leaves were removed every $2 \mathrm{~d}$, and cover fertilization was carried out every $10 \mathrm{~d}$, according to the soil analysis and recommendations for cultivation.

The experiment was conducted in a $2 \times 3 \times 3$ randomized complete block design, the factors being two hybrids (Netuno and San Vito), three doses of boron $\left(\mathrm{H}_{3} \mathrm{BO}_{3}-0,2,4 \mathrm{~g} /\right.$ pit$)$ and three frequencies of floral calcium applications $\left(\mathrm{CaCl}_{2}\right.$ at $0.6 \%$ ) (no application; application every $7 \mathrm{~d}$; and application every $14 \mathrm{~d}$ ) (Plese et al., 1998), totaling 18 treatments with four replicates and 20 plants per plot.

At $60 \mathrm{~d}$ after transplanting the seedlings, when all plants had produced the seventh floral cluster, the height (ALT, in $\mathrm{cm}$ ) of the plants was measured from the base to the apex using a tape measure. The fruits were harvested when they had yellowish spots. After harvesting, the fruits were counted and weighed daily using a digital scale, resulting in the following variables: total number of fruits per plant (NTF); total mass of fruits (MTF, g/plant); average fruit mass (MMF, g/plant); commercial fruit mass (MFC, $\mathrm{g} /$ plant) and non-commercial fruit mass (MFNC, g/ plant); number of commercial fruits (NFC) and noncommercial fruits (NFNC); mean fruit diameter (D, $\mathrm{cm}$ ) measured with a caliper; and total productivity (PROD, g).

In order to evaluate the relationships between the variables, Pearson's linear correlation coefficients were estimated. In order to perform path analysis without multicollinearity, the selection of the explanatory variables was done with the Stepwise method, and the following variables were selected: NTF, MTF, D, NFC and NFNC. After the selection of the variables with Stepwise, a multicollinearity diagnosis was performed between the explanatory variables through the analysis of the condition number

$$
N C=\frac{\lambda \max }{\lambda \min },
$$

which represents the ratio of the largest to the smallest eigenvalue of the correlation matrix, and the variance inflation factor

$V I F=\frac{1}{1-R_{i}^{2}}$, where $R_{j}^{2}$ the coefficient of determination is; after diagnosis, NFNC was excluded because there was high multicollinearity.

The path analysis was carried out with the Pearson correlation matrix, using the productivity variable (PROD) as the dependent variable. The path analysis coefficients were obtained with the methodology proposed by Cruz et al. (2012) using equation:

$Y=P_{o 1} X_{1}+P_{o 2} X_{2}+\ldots+P_{o n}+X_{n}+P_{u}$

were $Y$ is the coefficient of the dependent variable; $P_{\mathrm{o}}$ is the direct effect coefficient; $X$ is an explanatory independent variable; $P_{\mathrm{u}}$ is the residual effect and the standardization variable.

Statistical analyzes were performed at 5\% significance, with the MASS and agricolae packages available in the R program (R Core Team 2017).

\section{RESULTS}

The Pearson correlation analysis between the variables revealed several significant correlations. For the year 2012, the values showed a weak ALT correlation with the other variables. However, as expected, the NTF variable presented a strong correlation with 
the variables MTF, NFC, MFC $(0.98,0.93$ and 0.91 , respectively) and a negative correlation with the variables NFNC and MFNC (-0.65 and - 0.62 respectively). The variable MTF was positively correlated with four of the ten variables: NTF, NFC, MFC and PROD (0.98, 0.94, 0.94 and 1.00, respectively) and negatively correlated with NFNC and MFNC (-0.69 and -0.66 , respectively) (Tab. 1 ).

The variable NFC presented a significant and positive correlation with NTF, MTF, MFC, and PROD (0.93, 0.94, 0.98 and, 0.94 respectively), but was negatively correlated with NFNC and MFNC (-0.89 and -0.84 . respectively). NFNC showed a positive and strong correlation with MFNC (0.94) and, with the other variables, had a negative correlation, indicating that the higher the number of non-commercial fruits, the lower the production in general. The same was observed for the variable MFNC. The MFC and PROD variables presented a strong correlation with the NTF (0.91 and 0.98), MTF (0.94 and 1.00) and NFC (0.98 and 0.94$)$ variables, but was inversely proportional to NFNC (-0.87 and -0.69$)$ and MFNC (-0.87 and -0.66$)$ (Tab. 1).

For the year 2013, the relationships between the variables followed the same trend as 2012; however, they were moderately smaller, but still significant. Contrary to 2012, the variable MMF presented a higher correlation with the variables MTF, NFC, and MFC (0.56, 0.41 and 0.63 , respectively) (Tab. 1).
For the two years (2012 and 2013), the Stepwise method selected the NTF, MTF, D, NFC and NFNC variables for path analysis. However, the use of these variables caused a number of conditions (NC), and the values of inflation of variance (VIF) were high; thus, the NFNC variable was discarded from the analysis, and this action corrected the multicollinearity problem. Thus, the NC values were 165 and 30 for the years of 2012 and 2013, respectively. The VIF values for the year 2012 were 27.58, 31.30, 1.20 and 9.55. For the year 2012, the multicollinearity was moderate; however, in this case, this value did not imply serious problems because they are not much above those indicated. For the year 2013, the VIF values $(5.55,7.03,1.37$ and 3.64) were low.

In the year 2012, the decomposition of linear correlations in direct and indirect effects presented a coefficient of determination of $94 \%$ and a very low residual effect, proving that the selected variables explained a large part of the observed variation. The negative and negligible effect of the direct effect of the NTF $(-0.000019)$ and the positive and negligible effect of the direct effect of the NFC (0.000002) variables and the strong and positive correlation revealed that the correlation in the indirect effects explained the variable PROD. In the variable MTF, in which the direct effect was high and positive (1.000018), the correlation was also high and positive (1.00); the variable PROD was fully explained by the variable MTF; that is, it had a cause and effect relationship between the

Table 1. Estimates of the Pearson correlation coefficients for the variables height (ALT, $\mathrm{cm})$, total number of fruits per plant (NTF), total mass of fruits (MTF, g/plant), average fruit mass (MMF, g/plant), commercial fruit mass (MFC, g/plant) and non-commercial (MFNC, g/plant), number of commercial fruits (NFC) and non-commercial (NFNC), and mean fruit diameter $(\mathrm{D}, \mathrm{cm})$ total productivity (PROD, g) of two Italian tomato cultivars produced under different doses of boron and calcium application, in 2012 (upper diagonal) and 2013 (lower diagonal).

\begin{tabular}{|l|c|c|c|c|c|c|c|c|c|c|}
\hline Variables & ALT & NTF & MTF & D & NFC & NFNC & MFC & MFNC & PROD & MMF \\
\hline ALT & - & $0.03 \mathrm{~ns}$ & $0.04 \mathrm{~ns}$ & $0.18 \mathrm{~ns}$ & $0.05 \mathrm{~ns}$ & $-0.06 \mathrm{~ns}$ & $0.07 \mathrm{~ns}$ & $-0.09 \mathrm{~ns}$ & $0.04 \mathrm{~ns}$ & $0.08 \mathrm{~ns}$ \\
\hline NTF & $0.22 \mathrm{~ns}$ & - & $0.98^{*}$ & $0.25 \mathrm{~ns}$ & $0.93^{*}$ & $-0.65^{*}$ & $0.91^{*}$ & $-0.62^{*}$ & $0.98^{*}$ & $0.28 \mathrm{~ns}$ \\
\hline MTF & $0.31 \mathrm{~ns}$ & $0.88^{*}$ & - & $0.26 \mathrm{~ns}$ & $0.94^{*}$ & $-0.69^{*}$ & $0.94^{*}$ & $-0.66^{*}$ & $1.00^{*}$ & 0.46 \\
\hline D & $-0.16 \mathrm{~ns}$ & $0.02 \mathrm{~ns}$ & $0.22 \mathrm{~ns}$ & - & $0.36 \mathrm{~ns}$ & $-0.41^{*}$ & $0.35 \mathrm{~ns}$ & $-0.40^{*}$ & $0.26 \mathrm{~ns}$ & $0.14 \mathrm{~ns}$ \\
\hline NFC & $0.09 \mathrm{~ns}$ & $0.77^{*}$ & $0.84^{*}$ & $0.25 \mathrm{~ns}$ & - & $-0.89^{*}$ & $0.98^{*}$ & $-0.84^{*}$ & $0.94^{*}$ & $0.40^{*}$ \\
\hline NFNC & $0.15 \mathrm{~ns}$ & $-0.14 \mathrm{~ns}$ & $0.14 \mathrm{~ns}$ & -0.40 & $-0.53^{*}$ & - & $-0.87^{*}$ & $0.94^{*}$ & $-0.69^{*}$ & $-0.47^{*}$ \\
\hline MFC & $0.18 \mathrm{~ns}$ & $0.69^{*}$ & $0.89^{*}$ & $0.37 \mathrm{~ns}$ & $0.95^{*}$ & $-0.55^{*}$ & - & $-0.87^{*}$ & $0.94^{*}$ & $0.48^{*}$ \\
\hline MFNC & $0.21 \mathrm{~ns}$ & $-0.13 \mathrm{~ns}$ & $0.07 \mathrm{~ns}$ & -0.42 & $-0.49^{*}$ & $0.94^{*}$ & $-0.51^{*}$ & - & $-0.66^{*}$ & $-0.43^{*}$ \\
\hline PROD & $0.31 \mathrm{~ns}$ & $0.88^{*}$ & $1.00^{*}$ & $0.23 \mathrm{~ns}$ & $0.84^{*}$ & $-0.14 \mathrm{~ns}$ & $0.89^{*}$ & $-0.07 \mathrm{~ns}$ & - & $0.46^{*}$ \\
\hline MMF & $0.28 \mathrm{~ns}$ & $0.10 \mathrm{~ns}$ & $0.56^{*}$ & $0.48^{*}$ & $0.41^{*}$ & $-0.50^{*}$ & $0.63^{*}$ & $-0.34 \mathrm{~ns}$ & $0.56^{*}$ & - \\
\hline
\end{tabular}

ns - not significant; * - significant at $5 \%$ probability of error by the t-test 
variables. On the other hand, variable $\mathrm{D}$ had no cause and effect relationship with the main PROD variable (Tab. 2).

For the year 2013, the decomposition of linear correlations into direct and indirect effects showed a 99\% coefficient of determination and a low residual effect, so the selected variables explained a large part of the main PROD variable. The results were similar to those of 2012, with only minor changes related to the intensity of the effect. The negligible effect of the direct effect of the NTF (0.00219) and NFC (0.00142) variables and the strong and positive correlation revealed that the indirect effects explained the variable PROD. The variable MTF demonstrated a cause and effect relationship with the PROD variable as seen in 2012, and variable D had no direct or indirect effects on the main PROD variable (Tab. 2).

\section{DISCUSSION}

The variables ALT, D, MMF did not present a significant correlation with the other variables. Similarly, Sari et al. (2017) evaluated the linear relationships between cherry tomato characteristics and found a weak linear effect from the variables fruit length per plant, average fruit width per plant and average fruit weight per plant on the variables number of bunches per plant, number of fruits per plant and number of fruits per bunches.

In a study carried out by Kumar et al. (2013), a positive relationship was observed between fruit yield per plant and number of fruits per plant. Contrary to what was found in the present study, the same authors observed that fruit weight showed a strong correlation with fruit length and fruit diameter. The relationships between characteristics may change according to the cultivar or management adopted for the crop (Fallahi et al., 2017). In this way, the type of management adopted in the present study, different doses of boron and calcium applications, may have interfered with the relationships between the characteristics since boron actively participates in floral induction and maintenance of flowers in plants (Perica et al., 2001), leading to higher fruit yields and, consequently, higher yields. In addition, boron participates in the formation of the pollen tube and fruit formation, which contribute to the non-appearance of deformed fruits, thus reducing the number and mass of non-commercial fruits. In this study, it was possible to observe that, when there is an increase in positive

Table 2. Path analysis evaluated in two cultivars of Italian tomato submitted to doses of boron and calcium applications, involving the dependent variable productivity (PROD) and the explanatory independent variables, with the split of Pearson's correlations in components of direct effect (main diagonal, underline) and indirect (in the line) for the years of 2012 and 2013.

\begin{tabular}{|c|c|c|c|c|c|}
\hline \multicolumn{6}{|l|}{2012} \\
\hline Characteristic & NTF & MTF & D & NFC & $r$ \\
\hline NTF & -0.000019 & 0.981312 & -0.000002 & 0.000002 & 0.98 \\
\hline MTF & -0.000018 & $\underline{1.000018}$ & -0.000002 & 0.000002 & 1.00 \\
\hline $\mathrm{D}$ & -0.000005 & 0.261503 & -0.000008 & 0.000001 & 0.26 \\
\hline $\mathrm{NFC}$ & -0.000017 & 0.938043 & -0.000003 & $\underline{0.000002}$ & 0.94 \\
\hline Residual effect & $1.17 \times 10^{-9}$ & & & & \\
\hline$R^{2}$ & 0.94 & & & & \\
\hline \multicolumn{6}{|l|}{2013} \\
\hline NTF & $\underline{0.00219}$ & 0.87185 & -0.00002 & 0.00109 & 0.88 \\
\hline MTF & 0.00192 & $\underline{0.99623}$ & 0.00026 & 0.00120 & 1.00 \\
\hline D & -0.00004 & 0.22384 & $\underline{0.00115}$ & 0.00035 & 0.23 \\
\hline NFC & 0.00169 & 0.84073 & 0.00028 & $\underline{0.00142}$ & 0.84 \\
\hline Residual effect & $7.7 \times 10^{-4}$ & & & & \\
\hline$R^{2}$ & 0.99 & & & & \\
\hline
\end{tabular}

NTF: total number of fruits per plant; MTF: total mass of fruits; D: mean fruit diameter; NFC: number of commercial fruits; $r$ : Pearson's correlation coefficient. 
variables, a higher fruit production results in a negative correlation with the variables NFNC and MFNC.

Calcium is an essential macronutrient for plants because it actively participates in extracellular stimuli and intracellular responses that control a large amount of endogenous processes (Edel et al., 2017). In addition, it has role in cell wall structure and acts on factors that control the development of plants and responses to biotic and abiotic stresses (GonzálezFontes et al., 2017). This nutrient is also important for plant growth and fruit yield (Bastías et al., 2010). Thus, when tomato plants are under stress or suffer a nutrient deficiency, linear relationships between variables may be different.

The high values of the coefficient of determination $\left(R^{2}\right)$ and the low value of the residues indicated that there was precision in the estimates of the direct and indirect effects (Rios et al., 2012; Donazzolo et al., 2017). In the present study, the low values of NC and VIF may also have contributed to high $R^{2}$ values and low residual values in both evaluated years.

The results obtained from the path analysis were interpreted in the same way as Lúcio et al. (2013). That is, when the Pearson correlation coefficient was positive and indirect effects caused the direct effect negative or low, the correlation. Otherwise, if the Pearson correlation coefficient was low and the direct effect positive and high, the indirect effects were responsible for the lack of correlation. And when Pearson's correlation was negative and the direct effect positive and high, the indirect effects were eliminated from the analysis, and only the direct effect was conidered.

The use and interpretation of Pearson's correlation alone between variables can cause biased results since it does not employ the direct and indirect effects. So, the path analysis provides more reliable results that surpass the limitations of Pearson's correlation (Cruz et al., 2012). This was observed in the present study, that is, when the correlation between PROD and NTF was high this coefficient was used in the direct and indirect effects, it was observed that the NTF variable did not influence the $P R O D$ variable through cause and effect.

In both evaluated years, the path analysis revealed a cause and effect relationship between the MTF independent variable and the PROD dependent variable. This relationship was already expected since it is through the total mass of fruits that productivity is determined. Contrary to the present study, Sari et al. (2017) evaluated the linear relationships between characteristics of cherry tomatoes and concluded that production is directly related to the number of fruits produced and that the individual weight of each fruit has little influence on total production. In the present study, NTF presented low influence on the basic variable PROD. Rodrigues et al. (2010) observed that the variables mean weight of fruits and total number of fruits had high magnitudes of direct and indirect effects on total fruit production in saladtype tomatoes.

\section{CONCLUSION}

There were cause and effect relationships between the independent variable total mass of fruits and the main variable total fruit yield. The variables diameter and total number of fruits did not contribute substantially to an increased tomato production.

\section{ACKNOWLEDGMENTS}

The authors thank the National Council for Scientific and Technological Development (CNPq) and Coordination for the Improvement of Higher Education Personnel (CAPES) for supporting this study. We thank Paul Gallo and Duncan Hedderley for volunteering for the English grammar review.

Conflict of interests: this manuscript was prepared and reviewed with the participation of the authors, who declare that there exists no conflict of interest that puts at risk the validity of the presented results.

\section{BIBLIOGRAPHIC REFERENCES}

Alvares, C.A., J.L. Stape, P.C. Sentelhas, J.L. de Moraes Gonçalves, and G. Sparovek. 2013. Koppen's climate classification map for Brazil. Meteorol. Z. 22(6), 711-728. Doi: 10.1127/0941-2948/2013/0507

Bastías, E., C. Alcaraz-López, I. Bonilla, M.C. MartínezBallesta, L. Bolaños, and M. Carvajal. 2010. Interactions between salinity and boron toxicity in tomato plants involve apoplastic calcium. J. Plant Physiol. 167(1), 54-60. Doi: 10.1016/J.JPLPH.2009.07.014

Cruz, C.D., A.J. Regazzi, and P.C.S. Carneiro. 2012. Modelos biométricos aplicados ao melhoramento genético. $4^{\text {th }}$ ed. Editora UFV, Viçosa, Brazil.

Donazzolo, J., V.P. Salla, S.A.Z. Sasso, M.A. Danner, I. Citadin, and R.O. Nodari 2017. Path analysis for selection 
of feijoa with greater pulp weight. Ciênc. Rural 47(6), e20161062. Doi: 10.1590/0103-8478cr20161062

Edel, K.H., E. Marchadier, C. Brownlee, J. Kudla, and A.M. Hetherington. 2017. The evolution of calcium-based signalling in plants. Curr. Biol. 27(13), R667-R679. Doi: 10.1016/J.CUB.2017.05.020

Fallahi, H.-R., S.H.R. Ramazani, M. Ghorbany, and M. Aghhavani-Shajari. 2017. Path and factor analysis of roselle (Hibiscus sabdariffa L.) performance. J. Appl. Res. Med. Aromat. Plants 6, 119-125. Doi: 10.1016/J. JARMAP.2017.04.001

FAOSTAT, 2018. Crops - tomato. In: http://www.fao.org/ faostat/en/\#data/QC; consulted: May, 2018.

González-Fontes, A., M.T. Navarro-Gochicoa, C.J. Ceacero, M.B. Herrera-Rodríguez, J.J. Camacho-Cristóbal, and J. Rexach. 2017. Understanding calcium transport and signaling, and its use efficiency in vascular plants. pp. 165-180. In: Hossain, M.A., T. Kamiya, D.J. Burritt, L.S.P. Tran, and T. Fujiwara (eds.). Plant macronutrient use efficiency: molecular and genomic perspectives in crop plants. Elsevier, Cambridge, MA. Doi: 10.1016/ B978-0-12-811308-0.00009-0

Hocking, R.R. 1976. The analysis and selection of variables in linear regression. Biometric 32(1), 1-49. Doi: $10.2307 / 2529336$

Hosmer, D.W., B. Jovanovic, and S. Lemeshow. 1989. Best subsets logistic regression. Biometric 45(4), 1265 1270. Doi: $10.2307 / 2531779$

Kis, B.B. and C. Carvalho. 2017. Anuário brasileiro de hortaliças, 2017. Editora Gazeta, Santa Cruz do Sul, Brazil.

Kumar, D., R. Kumar, S. Kumar, M.L. Bhardwaj, M.C. Thakur, R. Kumar, K.S. Thakur, B.S. Dogra, A. Vikram, A. Thakur, and P. Kumar. 2013. Genetic variability, correlation and path coefficient analysis in tomato. Int. J. Veg. Sci. 19(4), 313-323. Doi: 10.1080/19315260.2012.726701

Lúcio, A.D., L. Storck, W. Krause, R.O. Gonçalves, and A.H. Nied. 2013. Relações entre os caracteres de maracujazeiro-azedo. Ciênc. Rural 43(2), 225-232. Doi: 10.1590/S0103-84782013000200006

Moreira, S.O., L.S.A. Gonçalves, R. Rodrigues, C.P. Sudré, A.T. Amaral Júnior, and A.M. Medeiros. 2013. Correlações e análise de trilha sob multicolinearidade em linhas recombinadas de pimenta (Capsicum annuum L.). Rev. Bras. Ciênc. Agrar. 8(1), 15-20. Doi: 10.5039/ agraria.v8i1a1726
Olivoto, T., V.Q. de Souza, V.Q., M. Nardino, I.R.Carvalho, M. Ferrari, A.J. de Pelegrin, V.J. Szareski, and D. Schmidt. 2017. Multicollinearity in path analysis: a simple method to reduce its effects. Agron. J. 109(1), 131-142. Doi: 10.2134/agronj2016.04.0196

Perica, S., P.H. Brown, J.H. Connell, A.M.S. Nyomora, C. Dordas, H. Hu, and J.Stangoulis. 2001. Foliar boron application improves flower fertility and fruit set of olive. HortScience 36(4), 714-716. Doi: 10.21273/ HORTSCI.36.4.714

Plese, L.P.M., C.S. Tiritan, E.I. Yassuda, L.I. Prochnow, J.E. Corrente, and S.C. Mello. 1998. Efeitos das aplicações de cálcio e de boro na ocorrência de podridão apical e produção de tomate em estufa. Sci. Agric. 55(1), 144 148. Doi: 10.1590/S0103-90161998000100023

R Core Team, 2017. R: A language and environment for statistical computing. R Foundation for Statistical Computing, Cary, NC.

Rafiei, F. and G.H.A. Saeidi. 2005. Genotypic and phenotypic relationships among agronomic traits and yield components in safflower (Carthamus tinctorious L.). Sci. J. Agric. 28(1), 137-148.

Rios, S.A., A. Borém, P.E.O. Guimarães, and M.C.D. Paes. 2012. Análise de trilha para carotenoides em milho. Rev. Ceres 59(3), 368-373. Doi: 10.1590/ S0034-737X2012000300011

Rodrigues, G.B., B.G. Marim, D.J.H. Silva, A.P. Mattedi, and V.S. Almeida. 2010. Análise de trilha de componentes de produção primários e secundários em tomateiro do grupo Salada. Pesq. Agropec. Bras. 45, 155-162. Doi: 10.1590/S0100-204X2010000200006

Sari, B.G., A.D. Lúcio, C.S. Santana, and S.J. Lopes. 2017. Linear relationships between cherry tomato traits. Ciênc. Rural 47(3), e20160666. Doi: $10.1590 / 0103-8478$ cr20160666

Toebe, M. and A.C. Filho. 2013. Não normalidade multivariada e multicolinearidade na análise de trilha em milho. Pesqui. Agropecu. Bras. 48(5), 466-477. Doi: 10.1590/S0100-204X2013000500002

Wright, S. 1923. The theory of path coefficients a reply to nile's criticism. Genetics 8(3), 239-255.

Zhang, Z., 2016. Variable selection with stepwise and best subset approaches. Ann. Transl. Med. 4(7), 136-136. Doi: 10.21037/atm.2016.03.35 